\title{
PENGARUH SEKTOR UNGGULAN TERHADAP PERTUMBUHAN EKONOMI DI KABUPATEN BANYUWANGI
}

\section{Ghozali Qubro, Sri Muljaningsih, Kiky Asmara}

Universitas Pembangunan Nasional (UPN) Veteran Jawa Timur, Indonesia

Email: ghozali.qubro98@gmail.com,sri_muljaningsih@yahoo.com, kikyasmara25@gmail.com

\begin{tabular}{ll}
\hline INFO ARTIKEL & ABSTRAK \\
\hline Diterima & Salah satu indikator peningkatan perbaikan pembangunan \\
25 Juli 2021 & ekonomi bisa dikenal melalui nilai pertumbuhan ekonomi. Nilai \\
Direvisi & pertumbuhan ekonomi ialah aspek yang bernilai dalam \\
05 Agustus 2021 & memperkirakan pencapaian kemajuan pembangunan ekonomi di \\
Disetujui & sesuatu wilayah. Nilai yang ada dalam PDRB sanggup \\
15 Agustus 2021 & merepresentasikan pertumbuhan ekonomi suatu daerah tersebut. \\
\hline Kata Kunci: & Oleh sebab itu, diperlukan analisis terhadap kawasan yang \\
sektor unggulan; & menjadi andalan sektor unggulan atau sektor basis untuk \\
LQ; shift share & mendorong pertumbuhan ekonomi di suatu daerah. Penelitian ini \\
& bertujuan untuk melihat pengaruh sektor unggulan terhadap \\
& pertumbuhan ekonomi di Kabupaten Banyuwangi. Metode yang \\
& digunakan oleh peneliti yaitu metode kuantitatif. Sampel yang \\
& digunakan dalam penelitian ini yaitu Kabupaten Banyuwangi \\
& tahun 2010-2019. Data yang digunakan oleh peneliti yaitu data \\
& sekunder dan bersifat time series dengan teknik analisis Location \\
& Qoutient $($ L) dan Shift Share yang diperoleh dari Badan Pusat \\
& Statistik Kabupaten Banyuwangi dan Provinsi Jawa Timur. Hasil \\
& dan pembahasan diketahui bahwa yang tergolong sektor \\
& unggulan di Kabupaten Banyuwangi terdapat 10 sektor \\
& sedangkan untuk sektor non unggulan terdapat 7 sektor. \\
& Pengaruh pola ekonomi sektor unggulan terhadap pertumbuhan \\
& ekonomi di Kabupaten Banyuwangi memiliki pengaruh positif \\
& atau signifikan dalam PDRB Kabupaten Banyuwangi, \\
& Sedangkan Untuk Pengaruh pola ekonomi sektor non unggulan \\
& terhadap pertumbuhan ekonomi di Kabupaten Banyuwangi \\
& pengaruh negatif atau tidak signifikan.
\end{tabular}

\section{ABSTRACT}

One indicator of increased improvement in economic development can be identified through the value of economic growth. The value of economic growth is a valuable aspect in estimating the achievement of economic development progress in an area. The value in GRDP can represent the economic growth of an area. Therefore, it is necessary to analyze the area that is

\begin{tabular}{ll}
\hline How to cite: & Qubro, G., Muljaningsih, S., \& Asmara, K. (2021) Pengaruh Sektor Unggulan terhadap \\
& Pertumbuhan Ekonomi Di Kabupaten Banyuwangi. Jurnal Syntax Admiration 2(8). \\
& https://doi.org/10.46799/jsa.v2i8.298 \\
E-ISSN: & $2722-5356$ \\
Published by: & Ridwan Institute
\end{tabular}




the mainstay of the leading sector or the base sector to
encourage economic growth in an area. This study aims to see
the influence of the leading sector on economic growth in
Banyuwangi Regency. The method used by the researcher is the
quantitative method. The sample used in this study is
Banyuwangi Regency in 2010-2019. The data used by the
researcher is secondary data and is time series with Location
Qoutient (LQ) and Shift Share analysis techniques obtained from
the Central Statistics Agency of Banyuwangi Regency and East
Java Province. From the results and discussion, it is known that
there are 10 sectors belonging to the leading sector in
Banyuwangi Regency, while for the non-leading sector there are
7 sectors. The influence of the leading sector economic pattern
on economic growth in Banywwangi Regency has a positive or
significant effect on the GRDP of Banyuwangi Regency, while
the influence of the non-sector economic pattern on economic
growth in Banyuwangi Regency has a negative or insignificant
effect.

\section{Pendahuluan}

Kabupaten Banyuwangi ialah salah satu Kabupaten dari 38 Kabupaten/ Kota di Provinsi Jawa Timur yang posisinya di ujung timur Pulau Jawa. Kabupaten Banyuwangi terdiri atas dataran tinggi berbentuk pegunungan yang ialah salah satu wilayah penghasil produk perkebunan, dataran rendah dengan bermacam potensi produk hasil pertanian dan juga ialah kawasan pesisir serta laut. Kabupaten Banyuwangi merupakan wilayah yang dianggap strategis disebabkan daerahnya merupakan penghubung antara Kabupaten- Kabupaten di pulau Jawa serta pulau Bali. Kemampuan perikanan di Kabupaten Banyuwangi sangat menguntungkan untuk wilayah, lebih- lebih jika dilihat dari sekian banyak hasil perikanan di Kabupaten Banyuwangi yang merupakan kategori ikan yang bernilai ekonomis tinggi.

Untuk memacu laju pertumbuhan ekonomi regional dan meningkatkan konstribusinya terhadap PDRB, hingga pembangunan sektor unggulan bisa dijadikan selaku penggerak pembangunan ekonomi (Ginting et al., 2020) Sektor unggulan bisa dikatakan sebagai sektor yang bisa menekan pertumbuhan ekonomi atau pertumbuhan untuk sektor-sektor yang lain, baik sektor yang menyuplai inputnya sampai sektor yang menggunakan output sektor unggulan tersebut selaku input dalam proses produksinya. Sedangkan itu, dalam pembangunan suatu negara tidak terlepas dari pembangunan wilayah secara menyeluruh sebagaimana pendapat menurut (Arsyad, 2010) yang menyatakan bahwa pembangunan ekonomi di suatu daerah merupakan proses kerja sama antara pihak pemerintah daerah dengan masyarakat dalam mengelola sumberdaya untuk menciptakan lapangan usaha atau lapangan pekerjaan serta dapat merangsang kegiatan ekonomi.

Perekonimian Kabupaten Banyuwangi pada tahun 2019 diyakini berkembang sebesar 5,86\%. Angka ini tercatat bertumbuh sangat besar dibanding wilayah lain yang 
biasa dikatakan daerah Sekar Kijang yang meliputi Situbondo, Jember, Bondowoso, Banyuwangi, serta Lumajang. Pertumbuhan ekonomi di Kabupaten Banyuwangi pada tahun 2019 nyatanya dinilai lebih unggul dari tahun tadinya, ialah sebesar 5,86\% dibandingkan 5,84\% pada tahun 2018. Di tengah perlambatan ekonomi, Banyuwangi terus mencatatkan kinerja positifm (Fu, 2020).

Rata- rata struktur ekonomi di Kabupaten Banyuwangi tercipta oleh sektor pertanian. Pada tahun 2012 kedudukan Sektor pertanian di Kabupaten Banyuwangi angkanya mencapai 46,24\%, ataupun nyaris 50\% dari aktivitas ekonomi di Kabupaten Banyuwangi bergerak pada sektor pertanian. Sektor pertanian mempunyai konstribusi yang cukup besar Tidak kalah pentingnya, Kabupaten Banyuwangi mempunyai kawasan yang strategis dalam bidang pariwisata. Pariwisata dapat mejadi komponen pendukung peningkatan pembangunan ekonomi di Kabupaten Banyuwangi, Salah satu program peningkatan kawasan strategis cepat tumbuh di kawasan Kabupaten Banyuwangi adalah adanya pemetaan kawasan pengembangan pariwisata (WPP) I dan (WPP) II (Pemerintah Kabupaten Banyuwangi, 2018).

Penelitian ini melihat perubahan dan pertumbuhan sektoral dalam perekonomian, serta menunjukkan sektor unggulan dan sektor non unggulan. Penelitian ini menggunakan analisis Location Quotient dan Shift Share dalam komponennya. Penelitian ini diharapkan dapat membantu Kabupaten Banyuwangi dalam mengembangkan potensi yang ada agar dapat mensejahterakan masyarakat setempat. Berdasarkan penelitiaan terdahulu, maka terdapat perbedaan. Perbedaannya terdapat pada kurun waktu dan tempat penelitian. Pada penelitian ini tempat dilakukan di daerah Kabupaten Banyuwangi dan penelitian ini dilakukan antara rentang waktu 2010 sampai dengan 2019.

Ada beberapa kajian yang relevan dan dimanfaatkan sebagai sumber prespektif dalam penelitian ini, khususnya penelitian yang di lakukan (Juhanis, 2012) Pengaruh Sektor Unggulan Terhadap Pertumbuhan Ekonomi Wilayah Kabupaten Halmahera Selatan. kemudian (Takalumang et al., 2018) Analisis Sektor Ekonomi Unggulan Dalam Mendorong Pertumbuhan Ekonomi Kabupaten/Kepulauan Sangihe dengan tahun 20102015. Selanjutnya penelitian dari (Syarifuddin \& T. Zulham, 2018) Analisis Sektor Unggulan Dan Pengaruhnya Terhadap Pertumbuhan Ekonomi Di Kabupaten Nagan Raya Provinsi Aceh. Kemudian penelitian dari (April, 2020) Analisis Sektor Unggulan Terhadap Pertumbuhan Ekonomi Di Provisi Sumatera Barat Tahun 2013-2017. Kemudian dari (Firmansyah, 2013) Analisis Penentuan Sektor Unggulan Perekonomian Dengan Metode Analytical Hierarchy Process (Ahp) Dan Shift Share Terhadap Pertumbuhan Ekonomi (Studi Di Kota Malang). dan yang terakhir penelitian yang dilakukan oleh (Tristanto, 2013) Analisis Sektor Ekonomi Unggulan Dalam Pengembangan Potensi Perekonomian Di Kota Blitar.

\section{Metode Penelitian}

Jenis penelitian yang digunakan adalah penelitian kuantitatif analisis statistik deskriptif yaitu untuk mengetahui sektor unggulan maupun sektor non unggulan di 
Kabupaten Banyuwangi, sektor unggulan ialah kemampuan ekonomi yang mungkin atau dapat dicapai untuk dikembangkan sehingga akan dapat menjadi sumber penghidupan rakyat setempat bahkan berdampak positif terhadap perekonomian wilayah secara keseluruhan untuk berkembang dengan sendirinya dan berkelanjutan (Suparmoko, 2012). Sedangkan sektor unggulan menurut (Miroah, 2015) yaitu: tingkat pertumbuhan sektor unggulan tinggi, tingkat penyerapan sektor unggulan relatif besar dalam penyerapan tenaga kerja, sektor unggulan akan memiliki tingkat keterkaitan yang tinggi dengan sektor yang lainnya dan dapat menciptakan nilai tambah yang tinggi.Tempat atau lokasi penelitian ini dilakukan di Kabupaten Banyuwangi. Sampel dalam penelitian ini, menggunakan data tahunan PDRB Kabupaten Banyuwangi dan data PDRB Provinsi Jawa Timur. Data penelitian ini bersifat time series tahun 20102019. Teknik pengumpulan data menggunakan studi kepustakaan dan studi lapangan. Definisi operasional atau pengukuran variabel menggunakan 2 jenis variabel, diantaranya yaitu variabel terikat dan variabel bebas, yang dimana varibel terikat merupakan pertumbuhan ekonomi, sedangkan variabel bebasnya yaitu sektor unggulan dan sektor non unggulan. Teknik analisis data dalam penelitian ini yaitu menggunakan teknik analisis Location Quotient (LQ) dan Analisis Shift Share.

\section{Hasil dan Pembahasan}

Pada hasil dan pembahasan terdapat dua hasil analisis. Berikut ini hasil dari Analisis Location Quotient (LQ) dan Analisis Shift Share :

\section{Analisis Location Quotient (LQ)}

Location Quotient digunakan untuk mengukur relative derajad spesialisasi suatu industri (kelompok industri) yang dipunyai oleh suatu daerah dibanding dengan daerah lain. Adapula yang digunakan sebagai pembanding umumnya merupakan daerah yang lebih luas maupun terlebih lagi setingkat nasional (Nugroho \& Dahuri, 2016).

Tabel 1

Hasil Perhitungan Analisis Sektor Unggulan dan Sektor Non Unggulan di Kabupaten Banyuwangi

\begin{tabular}{|c|c|c|c|c|c|c|c|c|c|c|c|c|}
\hline Kategori & Sektor & 2010 & 2011 & 2012 & 2013 & 2014 & 2015 & 2016 & 2017 & 2018 & 2019 & $\begin{array}{l}\text { Rata- } \\
\text { Rata }\end{array}$ \\
\hline A & $\begin{array}{l}\text { Pertanian, } \\
\text { Kehutanan, } \\
\text { dan Perikanan. }\end{array}$ & 2.64 & 2.82 & 3.15 & 3.48 & 3.79 & 4.16 & 4.35 & 4.44 & 4.53 & 4.52 & 3.79 \\
\hline B & $\begin{array}{l}\text { Pertambangan } \\
\text { dan Penggalian }\end{array}$ & 1.72 & 1.82 & 1.89 & 1.91 & 2.13 & 2.16 & 2.05 & 2.08 & 2.20 & 2.26 & 2.02 \\
\hline $\mathrm{C}$ & $\begin{array}{l}\text { Industri } \\
\text { Pengolahan }\end{array}$ & 0.40 & 0.43 & 0.45 & 0.47 & 0.48 & 0.51 & 0.54 & 0.55 & 0.56 & 0.57 & 0.49 \\
\hline D & $\begin{array}{l}\text { Pengadaan } \\
\text { Listrik dan Gas }\end{array}$ & 0.13 & 0.13 & 0.14 & 0.14 & 0.15 & 0.18 & 0.20 & 0.21 & 0.23 & 0.24 & 0.17 \\
\hline $\mathrm{E}$ & $\begin{array}{l}\text { Pengadaan Air, } \\
\text { Pengelolaan } \\
\text { Sampah, } \\
\text { Limbah dan }\end{array}$ & 0.66 & 0.68 & 0.74 & 0.78 & 0.83 & 0.87 & 0.90 & 0.88 & 0.89 & 0.91 & 0.81 \\
\hline
\end{tabular}




\begin{tabular}{|c|c|c|c|c|c|c|c|c|c|c|c|c|}
\hline & Daur Ulang & & & & & & & & & & & \\
\hline $\mathrm{F}$ & Konstruksi & 1.15 & 1.27 & 1.38 & 1.46 & 1.61 & 1.72 & 1.86 & 2.02 & 2.21 & 2.38 & 1.71 \\
\hline G & $\begin{array}{l}\text { Perdagangan } \\
\text { Besar dan } \\
\text { Eceran; } \\
\text { Reparasi Mobil } \\
\text { dan Sepeda } \\
\text { Motor }\end{array}$ & 0.74 & 0.80 & 0.86 & 0.93 & 0.98 & 1.06 & 1.14 & 1.22 & 1.31 & 1.39 & 1.04 \\
\hline $\mathrm{H}$ & $\begin{array}{l}\text { Transportasi } \\
\text { dan } \\
\text { Pergudangan }\end{array}$ & 1.01 & 1.05 & 1.10 & 1.19 & 1.31 & 1.42 & 1.53 & 1.60 & 1.63 & 1.70 & 1.36 \\
\hline I & $\begin{array}{l}\text { Penyediaan } \\
\text { Akomodasi } \\
\text { dan Makan } \\
\text { Minum }\end{array}$ & 0.43 & 0.44 & 0.48 & 0.53 & 0.58 & 0.63 & 0.68 & 0.73 & 0.77 & 0.81 & 0.61 \\
\hline $\mathrm{J}$ & $\begin{array}{l}\text { Informasi dan } \\
\text { Komunikasi }\end{array}$ & 0.95 & 0.96 & 0.95 & 0.93 & 0.95 & 1.00 & 1.03 & 1.06 & 1.09 & 1.12 & 1.01 \\
\hline K & $\begin{array}{l}\text { Jasa Keuangan } \\
\text { dan Asuransi }\end{array}$ & 0.73 & 0.78 & 0.81 & 0.83 & 0.88 & 0.93 & 0.97 & 1.02 & 1.05 & 1.07 & 0.91 \\
\hline $\mathrm{L}$ & Real Estate & 0.89 & 0.92 & 0.93 & 0.96 & 1.08 & 1.18 & 1.22 & 1.29 & 1.33 & 1.36 & 1.12 \\
\hline $\mathrm{M}, \mathrm{N}$ & $\begin{array}{l}\text { Jasa } \\
\text { Perusahaan } \\
\end{array}$ & 0.29 & 0.32 & 0.35 & 0.37 & 0.37 & 0.40 & 0.42 & 0.43 & 0.44 & 0.45 & 0.38 \\
\hline $\mathrm{O}$ & $\begin{array}{l}\text { Administrasi } \\
\text { Pemerintahan, } \\
\text { Pertahanan dan } \\
\text { Jaminan Sosial } \\
\text { Wajib }\end{array}$ & 0.96 & 1.02 & 1.10 & 1.17 & 1.25 & 1.35 & 1.44 & 1.54 & 1.58 & 1.59 & 1.30 \\
\hline $\mathrm{P}$ & $\begin{array}{l}\text { Jasa } \\
\text { Pendidikan }\end{array}$ & 1.20 & 1.33 & 1.44 & 1.47 & 1.52 & 1.57 & 1.61 & 1.69 & 1.76 & 1.78 & 1.54 \\
\hline Q & $\begin{array}{l}\text { Jasa Kesehatan } \\
\text { dan Kegiatan } \\
\text { Sosial }\end{array}$ & 0.60 & 0.60 & 0.60 & 0.61 & 0.63 & 0.66 & 0.72 & 0.77 & 0.81 & 0.82 & 0.68 \\
\hline $\mathrm{R}, \mathrm{S}, \mathrm{T}, \mathrm{U}$ & Jasa Lainnya & 0.79 & 0.84 & 0.85 & 0.89 & 0.93 & 1.02 & 1.11 & 1.24 & 1.35 & 1.39 & 1.04 \\
\hline
\end{tabular}

Berdasarkan tabel perhitungan $L Q$, jika dilihat dari nilai Location Quotient ( $L Q$ ) di Kabupaten Banyuwangi pada tahun 2010-2019 dengan kriteria LQ>1, maka terdapat sepuluh sektor yang mampu menjadi sektor unggulan di Kabupaten Banyuwangi diantaranya yaitu: Sektor Pertanian, Kehutanan, dan Perikanan. Sektor Pertambangan dan Penggalian. Konstruksi. Perdagangan Besar dan Eceran; Reparasi Mobil dan Sepeda Motor. Transportasi dan Pergudangan. Informasi dan Komunikasi. Real Estate. Administrasi Pemerintahan, Pertahanan dan Jaminan Sosial Wajib. Jasa Pendidikan. Jasa lainnya.

Terdapat juga Sektor Non Unggulan di Kabupaten Banyuwangi tahun 20102019 dengan kriteria LQ $<1$, diantaranya yaitu: Industri Pengolahan. Pengadaan Listrik dan Gas. Pengadaan Air, Pengelolaan Sampah, Limbah dan Daur Ulang. Penyediaan Akomodasi dan Makan Minum. Jasa Keuangan dan Asuransi. Jasa Perusahaan. Jasa Kesehatan dan Kegiatan Sosial. 


\section{Analisis Shift Share}

Transformasi ekonomi di suatu daerah yakni berarti palinh utama untuk pedoman dalam mengalokasikan dana pembangunan yang terbatas, sumberdaya manusia, teknologi serta input-input penting untuk produksi antar provinsi. Dalam perihal ini analisis yang biasanya digunakan untuk mengevaluasi pergantian struktur merupakan analisis Shift-Share (Khusaini, 2015). Analisis Shift Share membandingkan perbedaan laju pertumbuhan berbagai sektor industri di daerah dengan daerah nasional (Tarigan, 2005).

Hasil uji Shift Share "Proportional Shift" diatas tahun 2010-2019, maka didapatkan nilai tertinggi di tahun 2015-2016 yang dapat memberikan nilai positif berada di sektor pertambangan dan penggalian dengan tumbuh relatif cepat di tingkat Provinsi, sektor pertambangan dan penggalian dapat menjadi penopang perekonomian masyarakat di Kabupaten Banyuwangi. Sedangkan shift share "Proportional Shift" yang memberikan nilai negatif dengan menunjukkan angka tertinggi yaitu di tahun 2017-2018 yang berada di sektor Pertanian, Kehutanan, dan Perikanan. Hal tersebut dikarenakan pada tahun 2019 Nelayan Muncar yang ada di Kabupaten Banyuwangi adanya Keluhkan Hilangnya Ikan Lemuru, karena faktor alam yakni perubahan iklim.

Hasil uji Shift Share "Potential Regional" diatas tahun 2010-2019, yang mendapatkan angka tertinggi yaitu di tahun 2018-2019 berada di sektor Pertanian, Kehutanan, dan Perikanan dengan pertumbuhan produksi sektor di Kabupaten Banyuwangi tersebut cenderung mendorong pertumbuhan PDRB Provinsi Jawa Timur. Hal tersebut dikarenakan adanya salah satu penghasil produk perikanan terbesar di Jawa Timur. Sedangkan pada Shift Share "Potential Regional" yang menunjukkan pertumbuhan produksi sekitar Kabupaten Banyuwangi cenderung akan menghambat pertumbuhan PDRB Provinsi berada di tahun 2016-2017 pada sektor Pertanian, Kehutanan, dan Perikanan. Hal tersebut dikarenakan bahwa adanya pertumbuhan proporsional yang berbeda pada setiap sektor sehingga sangat dipengaruhi oleh kebijakan pemerintah yang berkaitan dengan pajak, subsidi dan kebijakan lain yang menyangkut tiap sektor sehingga dapat menghambat pertumbuhan PDRB Provinsi.

Hasil uji Shift Share "Differential Shift" diatas tahun 2010-2019, dapat dilihat bahwa nilai yang paling tinggi ada di tahun 2014-2015 berada di sektor Pertanian, Kehutanan, dan Perikanan. Hal tersebut dikarenakan bahwa di Kabupaten Banyuwangi pada sektor tersebut mempunyai sumber daya yang melimpah sehingga dapat memberikan nilai yang positif dan dapat dikatakan memiliki keuntungan lokasional serta mampu untuk dikembangkan. Sedangkan pada Shift Share "Differential Shift" yang memberikan nilai negatif dengan nilai tertinggi ada di tahun 2015-2016 yang berada pada sektor Pertambangan dan Penggalian. 


\section{Kesimpulan}

Sektor unggulan dan sektor non unggulan di dalam pola perekonomian Kabupaten Banyuwangi tahun 2010-2019 terdapat sepuluh sektor. Sektor unggulan, yang mempunyai nilai paling tertinggi berada di Sektor Pertanian, Kehutanan, dan Perikanan, Sektor non terdapat tujuh sektor Selain itu, di dalam sektor non unggulan nilai yang paling tinggi berada di sektor Jasa Keuangan dan Asuransi. Pengaruh pola ekonomi sektor unggulan terhadap pertumbuhan ekonomi di Kabupaten Banyuwangi memiliki pengaruh positif atau signifikan dalam PDRB Kabupaten Banyuwangi, hal tersebut dikarenakan bahwa sektor unggulan dapat dikembangkan dan bertujuan untuk meningkatkan pertumbuhan ekonomi. Sedangkan Untuk Pengaruh pola ekonomi sektor non unggulan terhadap pertumbuhan ekonomi di Kabupaten Banyuwangi pengaruh negatif atau tidak signifikan, hal tersebut dikarenakan bahwa sektor non unggulan berkembang kurang optimal dalam pengelolahan sehingga tingkat kesejahteraan masyarakat menurun, namun pemerintah Kabupaten Banyuwangi sudah melakukan peningkatan produktivitas pertanian. 


\section{BIBLIOGRAFI}

April, A. (2020). Analisis Sektor Unggulan Terhadap Pertumbuhan Ekonomi Di Provinsi Sumatera Barat Tahun 2013-2017. Iain Padang sidimpuan. Google Scholar

Arsyad, L. (2010). Ekonomi Pembangunan, Edisi Kelima. Yogyakarta: Upp Stie Ykpn. Google Scholar

Firmansyah, R. (2013). Perekonomian Dengan Metode Analytical Hierarchy Process (AHP) Dan Shift Share Terhadap Pertumbuhan Ekonomi. Jurnal Ilmiah. Universitas Brawijaya, Malang. Google Scholar

Fu, H. (2020). Pertumbuhan Ekonomi Banyuwangi Tertinggi di Kawasan Timur Jawa Berita Daerah. Berita Daerah.Co.Id. Google Scholar

Ginting, T., Sudibia, I. K., Dewi, N. P. M., \& MArhaeni, A. A. I. (2020). The Effect of Education and Dependency Ratio on Economic Growth and Poverty in Papua. American Journal of Humanities and Social Sciences Research (AJHSSR), 4(6), 186-195. Google Scholar

Juhanis. (2012). Pengaruh Sektor Unggulan Terhadap Pertumbuhan Ekonomi Wilayah Kabupaten Halmahera Selatan. Jurnal Plano Madani, I (1), 16-28. Google Scholar

Khusaini, M. (2015). A shift-share analysis on regional competitiveness-a case of Banyuwangi district, East Java, Indonesia. Procedia-Social and Behavioral Sciences, 211, 738-744. Google Scholar

Miroah, C. (2015). Analisis Penentuan Sektor Unggulan Kota Semarang Melalui Pendekatan Tipologi Klassen. Universitas Negeri Semarang. Google Scholar

Nugroho, I., \& Dahuri, R. (2016). Pembangunan Wilayah: Perspektif ekonomi, sosial dan lingkungan. LP3ES. Google Scholar

Pemerintah Kabupaten Banyuwangi. (2018). Rencana Kerja Pembangunan Daerah Kabupaten Banyuwangi tahun 2018 (Pemerintah Kabupaten Banyuwangi (ed.)). Pemerintah Kabupaten Banyuwangi. Google Scholar

Suparmoko, M. (2012). Ekonomika pembangunan. Edisi Keenam, Cetakan Pertama. BPFE Fakultas Ekonomi Universitas Gajah Mada: Yogyakarta. Google Scholar

Syarifuddin, T., \& T. Zulham. (2018). Analisis Sektor Unggulan Dan Pengaruhnya Terhadap Pertumbuhan Ekonomi Di Kabupaten Nagan Raya Provinsi Aceh. Jurnal Ilmiah Mahasiswa (JIM), 3 (4), 845-852. Google Scholar 
Takalumang, V. Y., Rumate, V. A., Lapian, A. L. C. P., Pembangunan, J. E., Ekonomi, F., Sam, U., \& Takalumang, V. (2018). Analisis Sektor Ekonomi Unggulan Dalam Mendorong Pertumbuhan Ekonomi Kabupaten/Kepulauan Sangihe. Jurnal Berkala Ilmiah Efisiensi, 18 (01), 1-12. Google Scholar

Tarigan, R. (2005). Perencanaan pembangunan wilayah. PT. Bumi Aksara. Google Scholar

Tristanto, A. H. (2013). Analisis Sektor Ekonomi Unggulan Dalam Pengembangan Potensi Perekonomian Di Kota Blitar. Jurnal Ilmiah Mahasiswa FEB, 1 (2), 1-30. Google Scholar

\section{Copyright holder:}

Ghozali Qubro, Sri Muljaningsih, Kiky Asmara (2021)

\section{First publication right:}

Jurnal Syntax Admiration

This article is licensed under: 